\title{
Microphysical properties and high ice water content in continental and oceanic mesoscale convective systems and potential implications for commercial aircraft at flight altitude
}

\author{
J.-F. Gayet ${ }^{1}$, V. Shcherbakov ${ }^{1,2}$, L. Bugliaro ${ }^{3}$, A. Protat ${ }^{4}$, J. Delanoë ${ }^{5}$, J. Pelon ${ }^{5}$, and A. Garnier ${ }^{6}$ \\ ${ }^{1}$ Laboratoire de Météorologie Physique, UMR6016 CNRS/Université Blaise Pascal, Clermont-Ferrand, France \\ ${ }^{2}$ Laboratoire de Météorologie Physique, Institut Universitaire de Technologie d'Allier, Montluçon, France \\ ${ }^{3}$ Deutsches Zentrum für Luft- und Raumfahrt (DLR), Institut für Physik der Atmosphäre, Oberpfaffenhofen, Germany \\ ${ }^{4}$ Centre for Australian Weather and Climate Research (CAWCR), Melbourne, Australia \\ ${ }^{5}$ Laboratoire Atmosphères, Milieux, Observations Spatiales, UMR8190 CNRS/Université Pierre et Marie Curie, Guyancourt, \\ France \\ ${ }^{6}$ Centre National de la Recherche Scientifique, currently Science Systems and Applications, Inc./NASA Langley Research \\ Center, USA
}

Correspondence to: J.-F. Gayet (j.f.gayet@opgc.univ-bpclermont.fr)

Received: 13 June 2013 - Published in Atmos. Chem. Phys. Discuss.: 29 August 2013

Revised: 20 November 2013 - Accepted: 12 December 2013 - Published: 27 January 2014

\begin{abstract}
Two complementary case studies are conducted to analyse convective system properties in the region where strong cloud-top lidar backscatter anomalies are observed as reported by Platt et al. (2011). These anomalies were reported for the first time using in situ microphysical measurements in an isolated continental convective cloud over Germany during the CIRCLE2 experiment (Gayet et al., 2012). In this case, in situ observations quasi-collocated with CALIPSO (Cloud Aerosol Lidar and Infrared Pathfinder Satellite Observation), CloudSat and Meteosat-9/SEVIRI observations confirm that regions of backscatter anomalies represent the most active and dense convective cloud parts with likely the strongest core updrafts and unusually high values of the particle concentration, extinction and ice water content (IWC), with the occurrence of small ice crystal sizes. Similar spaceborne observations of a maritime mesoscale cloud system (MCS) located off the Brazilian coast between $0^{\circ}$ and $3^{\circ} \mathrm{N}$ latitude on 20 June 2008 are then analysed. Near cloud-top backscatter anomalies are evidenced in a region which corresponds to the coldest temperatures with maximum cloud top altitudes derived from collocated CALIPSO/IIR and Meteosat-9/SEVIRI infrared brightness temperatures. The interpretation of CALIOP (Cloud Aerosol Lidar with Orthogonal Polarization) data highlights signifi-
\end{abstract}

cant differences in microphysical properties from those observed in the continental isolated convective cloud. Indeed, SEVIRI (Spinning Enhanced Visible and InfraRed Imager) retrievals in the visible spectrum confirm much smaller ice particles near the top of the isolated continental convective cloud, i.e. effective radius $\left(R_{\mathrm{eff}}\right) \sim 15 \mu \mathrm{m}$ as opposed to 22 $27 \mu \mathrm{m}$ in the whole MCS area. Cloud profiling observations at $94 \mathrm{GHz}$ from CloudSat are then used to describe the properties of the most active cloud regions at and below cloud top. The cloud ice-water content and effective radius retrieved with the CloudSat 2B-IWC and DARDAR (raDAR/liDAR) inversion techniques, show that at usual cruise altitudes of commercial aircraft (FL 350 or $\sim 10700 \mathrm{~m}$ level), high IWC (i.e. up to 2 to $4 \mathrm{~g} \mathrm{~m}^{-3}$ ) could be identified according to specific IWC $-Z$ ( $Z$ being the reflectivity factor) relationships. These values correspond to a maximum reflectivity factor of $+18 \mathrm{dBZ}$ (at $94 \mathrm{GHz}$ ). Near-top cloud properties also indicate signatures of microphysical characteristics according to the cloud-stage evolution as revealed by SEVIRI images to identify the development of new cells within the MCS cluster. It is argued that the availability of real-time information (on the kilometre-scale) about cloud top IR brightness temperature decreases with respect to the cloud environment would help identify MCS cloud areas with potentially 
high ice water content and small particle sizes against which onboard meteorological radars may not be able to provide timely warning.

\section{Introduction}

Platt et al. (2011, called PL hereafter) investigated backscatter anomalies in mesoscale convective systems (MCSs) using CALIOP (Cloud Aerosol Lidar with Orthogonal Polarization; Hunt et al., 2009) observations on-board the CALIPSO (Cloud Aerosol Lidar and Infrared Pathfinder Satellite Observation; Winker et al., 2009) platform. They showed that the microphysical cloud properties are different in regions near the centre of large MCSs from in surrounding clouds. These regions, extending over a few tens of kilometres, are the most active, with the coldest top temperatures and with maximum cloud extinction and altitude. Simultaneous CloudSat cloud profiling radar (CPR; Stephens et al., 2002) observations showed a cloud-top altitude similar to that measured by CALIOP. This feature likely suggests that relatively large ice crystals above the radar detection threshold were reaching cloud top. From the depolarization ratio measurements, PL suggested that the CALIOP and CloudSat returns were likely due to a mix of frozen drops or small ice droxtals with large crystals composed of thick hexagonal plates, hexagonal columns, spheroids, and irregular particles.

The same phenomenon was observed for the first time over Europe with aircraft in situ microphysical observations in an isolated continental convective cloud during the CIRCLE2 experiment (Eichler et al., 2009) over Germany on 26 May 2007. Indeed, we have shown (Gayet et al., 2012, called GA hereafter) that unusually high values for the concentration of small ice particles, extinction and ice water content (up to $70 \mathrm{~cm}^{-3}, 30 \mathrm{~km}^{-1}$ and $0.5 \mathrm{~g} \mathrm{~m}^{-3}$, respectively) occurred at near the top of an overshooting convective cloud $\left(11080 \mathrm{~m} /-58^{\circ} \mathrm{C}\right)$. A chain-like aggregate of frozen droplets was the main shape of the ice crystals with a maximum particle size and mean effective diameter of $300 \mu \mathrm{m}$ and $43 \mu \mathrm{m}$, respectively. The airborne observations were coordinated with satellite observations, which allowed the cloud situation to be coherently described by combined remote sensing measurements. The very dense cloud causes a strong attenuation of the CALIOP lidar returns and the Meteosat9 (MET-9)/SEVIRI retrieved parameters, (Bugliaro et al., 2011) confirming the presence of small ice crystals at the top of the convective cell. Due to the chain-like aggregate shape of the small ice crystals, the power-law relationship between ice water content (IWC) and radar reflectivity $(Z)$ appears to be different from those usually found in cirrus and anvil clouds. IWC is significantly larger in the overshooting cell than in the cirrus cloud for a given equivalent reflectivity factor. Extrapolating the relationship for stronger convective clouds, IWC up to $5 \mathrm{~g} \mathrm{~m}^{-3}$ could be experienced with $94 \mathrm{GHz}$ reflectivity factors no larger than about $20 \mathrm{dBZ}$. This means that for similar situations, a rather weak radar echo could fail to indicate the occurrence of high ice water content carried by small ice crystals. This has been recognized as a significant hazard for air traffic safety (e.g., Mason et al., 2006).

In anvils of intense mid-latitude storms over the Great Plains of USA, IWC from 1.5 to $2.5 \mathrm{~g} \mathrm{~m}^{-3}$ was reported (Heymsfield and Palmer, 1986, Lawson et al., 1998). Ice water content exceeding $2 \mathrm{~g} \mathrm{~m}^{-3}$ and extinction up to $60 \mathrm{~km}^{-1}$ have been measured in tropical convective turrets clouds (Lawson et al., 2010). Heymsfield et al. (2005a, 2006) reported a high concentration of small ice crystals (in the order of $50 \mathrm{~cm}^{-3}$ ) in subtropical and tropical convection, even in maritime tropical convective updrafts (Heymsfield et al., 2009). Although ice particle concentrations measured by the Forward Scattering Spectrometer Probe (FSSP) are generally overestimated due to shattering effects (see among others Korolev and Isaac, 2005) these unusual observations could be important regarding engineering issues related to the failures of jet engines and Pitot tubes commonly used on commercial aircraft during flights through areas of high ice water content (Lawson et al., 1998; Strapp et al., 1999; Mason et al., 2006). Mason et al. (2006) mentioned that commercial aircraft often observe no flight-radar echoes at the location and altitude of such events.

The objectives of this paper are first to apply PL's analysis to the CALIPSO lidar (CALIOP) backscatter properties related to the isolated continental convective cloud (26 May 2007 CIRCLE2 situation). CloudSat and MET-9/SEVIRI observations combined with available quasi-collocated in situ measurements are analysed in order to obtain a consistent interpretation of these spaceborne remote sensing observations. Then, for comparison purposes we analyse similar spaceborne observations (from measured near-cloud top backscatter anomalies) regarding a maritime MCS on the 20 June 2008 located off the Brazilian coast between $0^{\circ}$ and $3^{\circ} \mathrm{N}$ latitude, in order to select the most-active MCS regions, which are likely to have the densest clouds and strongest updrafts. The use of collocated MET-9/SEVIRI real-time data is then discussed to describe the properties of the MCS regions most likely to be active, which could be encountered by commercial aircraft at usual cruise altitudes (FL 350 or $\sim 10700 \mathrm{~m}$ level)

\section{Satellite data}

In this paper we use CALIPSO, CloudSat and MET-9 observations. Satellite data have been described in detail in GA. We summarize the main payload and technical characteristics of the available observations below.

The payload of the CALIPSO satellite includes the CloudAerosol Lidar with Orthogonal Polarization (CALIOP), the Imaging Infrared Radiometer (IIR) and the Wide Field Camera (WFC) (Winker et al., 2010). CALIOP is a laser operating 
at $532 \mathrm{~nm}$ and $1064 \mathrm{~nm}$, with parallel and orthogonal polarization detectors at $532 \mathrm{~nm}$ (Winker et al., 2003; Hunt et al., 2009). The vertical and horizontal resolutions of the attenuated backscatter coefficient product used here are $60 \mathrm{~m}$ and $1 \mathrm{~km}$, respectively. IIR is a non-scanning imaging radiometer, nadir-viewing with a $69 \mathrm{~km}$ swath, and a pixel size of $1 \mathrm{~km}$, which provides measurements in the thermal infrared atmospheric window region at $8.65 \mu \mathrm{m}, 10.6 \mu \mathrm{m}$, and $12.05 \mu \mathrm{m}$ with a bandpass of $0.9 \mu \mathrm{m}, 0.6 \mu \mathrm{m}$ and $1 \mu \mathrm{m}$, respectively (Garnier et al., 2012). The CALIOP beam is nominally aligned with the centre of the IIR image. WFC is a fixed, nadir-viewing imager with a single spectral channel covering the $620-670 \mathrm{~nm}$ region, selected to match band 1 of the MODIS (MODerate resolution Imaging Spectroradiometer) instrument on NASA's Aqua satellite. The instantaneous field of view (IFOV) and swath are 125 and $61 \mathrm{~km}$, respectively.

CloudSat carries a $94 \mathrm{GHz}(3.2 \mathrm{~mm})$ cloud profiling radar (CPR) to provide the vertical distribution of hydrometeors (Stephens et al., 2002). The CPR has a nominal vertical resolution of $500 \mathrm{~m}$ and a footprint of $1.4 \times 1.7 \mathrm{~km}^{2}$ (cross- and along-track) for a CPR profile.

The MET-9 satellite's main payload is the Spinning Enhanced Visible and InfraRed Imager (SEVIRI). It provides image data in four visible and near-infrared channels (0.4$1.6 \mu \mathrm{m})$ and eight InfraRed channels $(3.9-13.4 \mu \mathrm{m})$. Sampling distances are $1 \mathrm{~km}$ for the high resolution visible channel and $3 \mathrm{~km}$ for the infrared and the three other solar channels.

\section{Analysis of the CALIOP backscatter and CloudSat data of the 26 May 2007 isolated continental convective cloud}

Figure 1a-c display a composite representation (from top to bottom) of IIR brightness temperature images at $10.6 \mu \mathrm{m}$, the vertical profiles from CALIOP (attenuated backscatter coefficient) and the equivalent reflectivity factor from CloudSat, respectively. These observations are plotted across the convective system on 26 May 2007 along the CALIPSO track, i.e. between 48.0 and $50.0^{\circ} \mathrm{N}$ latitude. This situation has already been discussed in a previous paper (see GA) including a detailed in situ microphysical description. These observations address an isolated continental convective cloud over Germany. The CALIOP data (Fig. 1b) were obtained from the version 3.0 data products (available at the NASA Langley Atmospheric Science Data Centre and the ICARE mirror site in France). The CALIOP profiles used correspond to resolutions of $1 \mathrm{~km}$ horizontally (e.g. averaged over 3 laser shots) and $60 \mathrm{~m}$ vertically. In Fig. 1d, the integrated attenuated backscatter is shown along the latitude and Fig. 1e represents the integrated volume depolarization ratio. Figure $1 \mathrm{~b}$ shows a typical increase of the backscatter coefficient in the overshooting cell (which reaches $11000 \mathrm{~m} /-58^{\circ} \mathrm{C}$ level) and

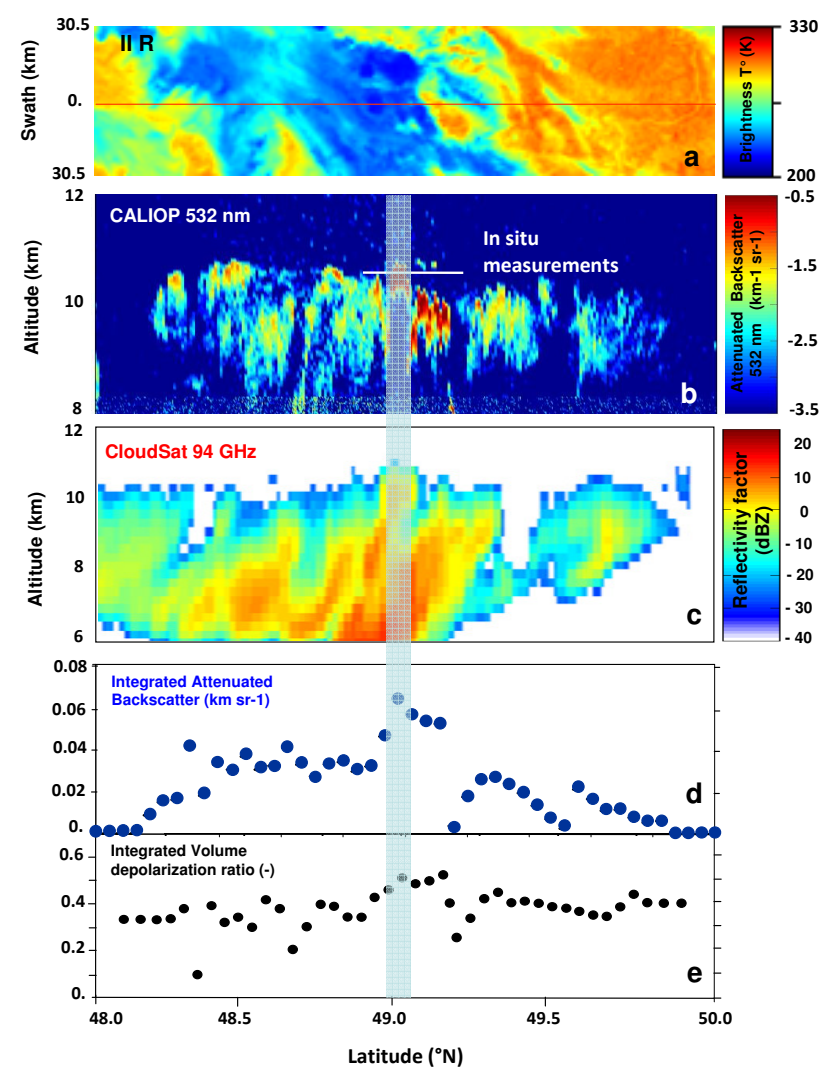

Fig. 1. (a) Imaging Infrared Radiometer (IIR); (b) vertical profile of the CALIOP $532 \mathrm{~nm}$ attenuated backscatter coefficient; (c) vertical profile of the equivalent reflectivity factor from CloudSat; (d) integrated attenuated backscatter (log-scale); and (e) integrated depolarization ratio. These observations are plotted along the CALIPSO track, i.e. between 48.5 and $49.5^{\circ} \mathrm{N}$ across the convective system on 26 May 2007 (12:32 UTC). The shaded area indicates the active part of the overshooting cell.

in the adjacent growing clouds. IIR gives information that is exactly collocated in time and space with CALIOP information. The temperature of the cloud top deduced from the IR brightness temperature is in good agreement with the lidar value, showing that this part of the cloud is dense. The value retrieved from the SEVIRI data (Bugliaro et al., 2011) is in good agreement with that from IIR, and offers an extended swath. Lower lidar return signals are observed in the surrounding outflow cirrus layer. The integrated attenuated backscatter (Fig. 1d) peaks up to $0.07 \mathrm{sr}^{-1}$, a larger value than those reported by PL in tropical MCS (i.e. $0.055 \mathrm{sr}^{-1}$ ). In the surrounding outflow cirrus, typical values range between 0.03 and $0.04 \mathrm{sr}^{-1}$.

The integrated depolarisation ratio (Fig. 1e) changes concurrently with the largest values, increasing up to 0.54 , whereas the mean value of 0.40 is observed in the surrounding outflow cirrus cloud. Cloud properties derived from CALIOP measurements are summarized in Table 1. As proposed by PL, we reported quantities for baseline 
Table 1. Baseline and enhanced integrated attenuated backscatter values ( $\gamma_{\mathrm{b}}^{\prime}$ and $\gamma_{\mathrm{e}}^{\prime}$, respectively), baseline and enhanced values of isotropic backscatter-to-extinction ratio $\left(k_{\mathrm{b}}\right.$ and $\left.k_{\mathrm{e}}\right)$ for $\eta=0.6$, baseline and enhanced (or reduced) of the integrated depolarisation ratios $\left(\Delta_{\mathrm{b}}\right.$ and $\left.\Delta_{\mathrm{e}}\right)$, change in depolarization ratio from baseline value $\left(d \Delta=\Delta_{\mathrm{e}}-\Delta_{\mathrm{b}}\right)$ and cloud-top temperature $\left(T_{\mathrm{t}}\right)$. The results are reported for the two cloud situations described in this paper (26 May 2007 and 20 June 2008).

\begin{tabular}{|c|c|c|c|c|c|c|c|c|}
\hline Date & $\gamma_{\mathrm{b}}^{\prime}$ & $\gamma_{\mathrm{e}}^{\prime}$ & $k_{\mathrm{b}}$ & $k_{\mathrm{e}}$ & $\Delta_{\mathrm{b}}$ & $\Delta_{\mathrm{e}}$ & $d \Delta$ & $T_{\mathrm{t}}$ \\
\hline 26 May 2007 & 0.04 & 0.070 & 0.60 & 1.06 & 0.40 & 0.54 & +0.14 & $-58^{\circ} \mathrm{C}$ \\
\hline 20 June 2008 Part A & \multirow{2}{*}{0.03} & \multirow{2}{*}{0.043} & \multirow{2}{*}{0.45} & \multirow{2}{*}{0.65} & 0.38 & 0.44 & +0.06 & \multirow[t]{2}{*}{$-75^{\circ} \mathrm{C}$} \\
\hline 20 June 2008 Part B & & & & & 0.38 & 0.29 & -0.09 & \\
\hline
\end{tabular}

and enhanced values. The values away from the enhanced backscatter correspond to the baseline. The enhanced values are the peak values of the integrated backscatter and the peak or minimum values of the depolarization ratio. Following PL, the isotropic backscatter-to-extinction ratio $(k)$ is calculated considering the lidar signal fully attenuated by the cloud, i.e.:

$k=2 \eta \gamma^{\prime}(\pi)$,

where $\eta$ is the multiple scattering factor $(0.6)$ and $\gamma^{\prime}(\pi)$ is the integrated attenuated isotropic backscatter obtained by multiplying the CALIOP integrated attenuated backscatter (IAB) by $4 \pi$. According to radiative transfer analyses, $k$ values depend on the ice particle shape (Noël et al., 2004), but it has recently been found from CALIPSO observations that relatively constant values $(k \sim 0.40)$ were observed in the atmosphere for non-opaque ice clouds (Josset et al., 2012), possibly due to mixture of particles with different shapes. The enhanced value of $k_{\mathrm{e}}$ of 1.06 in Table 1 is fairly larger than the theoretical values provided by PL (see Table 2) for randomly oriented ice crystals with different shapes. This may correspond to droxtals particles (Yang et al., 2003). Information on the particle shape may also be given by the values of the integrated depolarization ratio $\left(\Delta_{\mathrm{e}}\right.$, see Table 1$)$. A value of 0.54 corresponds closely to the calculations by Takano and Liou (1989) for hexagonal columns. It is also expected that $\Delta_{\mathrm{e}}$ should also increase with cloud optical depth and larger number of small particles due to multiple scattering as in water clouds (Hu et al., 2007). Thus small particles such as frozen droplets could be mixed with larger ice crystals.

The in situ measurements taken near the top of the overshooting cell (see GA) reveal unusually high values for the concentration of small ice particles, extinction and ice water content (up to $70 \mathrm{~cm}^{-3}, 30 \mathrm{~km}^{-1}$ and $0.5 \mathrm{~g} \mathrm{~m}^{-3}$, respectively). Although in situ observations were carried out 30 min after the CALIPSO overpass, these unusual microphysical cloud properties may explain backscatter anomalies near the top of the overshooting cell. Chain-like aggregates of frozen droplets were the dominant form of the ice crystals (see Figs. 8 and 10 in GA) with a maximum particle size and mean effective diameter of $300 \mu \mathrm{m}$ and $43 \mu \mathrm{m}$, respec-

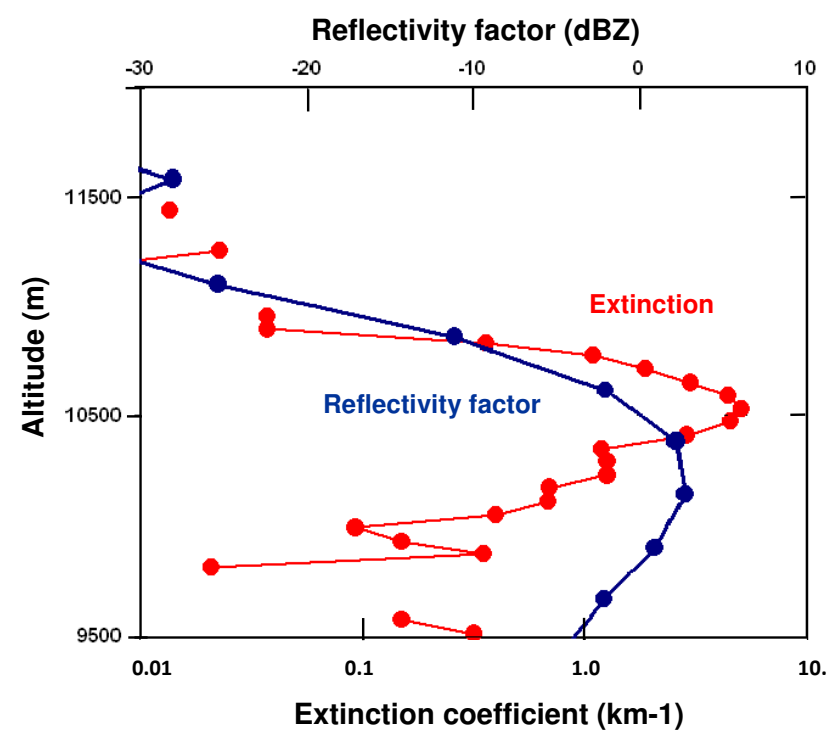

Fig. 2. Vertical profiles of the extinction coefficient and the reflectivity factor at the centre of the overshooting cell $\left(48.97^{\circ} \mathrm{N}\right.$, see Fig. 1). 26 May 2007 cloud situation.

tively. Analysis of SEVIRI observations in the visible spectrum gave an average particle size of about $20 \mu \mathrm{m}$, in good agreement with in situ observations (see GA).

Figure 2 displays the vertical profiles of the extinction coefficient and the reflectivity factor at the centre of the overshooting cell $\left(48.97^{\circ} \mathrm{N}\right.$, see Fig. 1b). The extinction coefficient was derived from the CALIOP attenuated backscattering profiles using the technique described by Noël et al. (2007) to retrieve extinction in the tops of deep convective clouds. The reflectivity is obtained from the $2 \mathrm{~B}$ GEOPROF product and is available from the data processing centre (DPC) operated by the Colorado State University. The results in Fig. 2 show a sharp increase of the extinction coefficient from the cloud top $\left(11000 \mathrm{~m}\right.$ ) to $10450 \mathrm{~m}$ (up to $5 \mathrm{~km}^{-1}$ ), and then the signal is rapidly attenuated at lower altitudes. The reflectivity factor reveals detectable signal (> -30 dBZ) even near the cloud top, indicating the presence of ice particles large enough to be detected by CloudSat radar. According to PL, the minimum detectable particle size is $30-40 \mu \mathrm{m}$ 
in terms of the effective radius of a distribution of equivalentmass spheres, values which are within the range of in situ observations (see GA).

To conclude, similar backscatter anomalies as reported by PL in maritime MCS were observed for the first time near the top of an isolated continental convective cloud during the CIRCLE2 experiment. Quasi-collocated in situ observations confirm that these regions represent the most active and dense convective cloud parts with likely the strongest core updrafts and unusually high values for the concentration of small ice particles, extinction and ice water content. Retrieved extinction from lidar data analysis confirmed unusually large values near ice cloud top (in excess of $3 \mathrm{~km}^{-1}$ ). For ice cloud particles with a $30 \mu \mathrm{m}$ average diameter, this would lead to an average number of particles of about $1000 \mathrm{~L}^{-1}$, using geometric optics approximation. Vigorous updrafts could lift supercooled droplets, which are frozen extremely rapidly by homogeneous nucleation near the $-37^{\circ} \mathrm{C}$ level, producing therefore high concentrations of small ice particles at upper altitudes. Moreover, the observed dominant ice particle shape (a chain-like aggregate of frozen droplets) is mostly observed in continental deep convective systems (Stith et al., 2002; Lawson et al., 2003; Connolly et al., 2005) which generate intense electric fields causing efficient ice particle aggregation processes.

The next section will describe a maritime mesoscale cloud system located off the Brazilian coast on 20 June 2008 which presents similar near-cloud top backscattering anomalies.

\section{Description of the 20 June 2008 maritime mesoscale convective system}

For comparison purposes we looked for a case of a welldeveloped mesoscale convective cloud system over the tropical Atlantic Ocean. This system has to be observed by the CALIPSO and the CloudSat during daylight hours in order to simultaneously derive some of its parameters from visible radiometry. We selected the case of the 20 June 2008 for which the CALIPSO track was very close to the centre of an active cloud cell. The CALIPSO/CloudSat satellites overpassed this mesoscale convective cloud system located off the Brazilian coast between $0^{\circ}$ and $3^{\circ} \mathrm{N}$ latitude at 15:43 UTC. CALIPSO and CloudSat observations reveal backscatter anomalies similar to those described in the isolated convective cloud previously analysed. This confirms the hypothesis that the satellites overpassed the most active parts of the MCS parts - those with the coldest temperatures (simultaneously observed with the IIR) and with maximum cloud altitude.

We shall first analyse the MET-9/SEVIRI observations available in this area in order to assess the activity of the MCS in terms of cloud top temperature and altitude near the CALIPSO/CloudSat overpasses, as well as microphysical parameters. Then we shall discuss the active sensing measurements, and finally we will analyse the parameters retrieved from CloudSat data (ice water content and effective radius) in order to describe cloud properties at the usual cruise altitudes of commercial aircraft, which likely prevailed in the most active parts of the MCS in the mid-tropical troposphere.

\subsection{Analysis of the MET-9/SEVIRI data}

Figure $3 \mathrm{a}$ and $\mathrm{b}$ display the images of false colour composites from MET-9/SEVIRI data and brightness temperature $(10.8 \mu \mathrm{m}$ channel), respectively, over the scene defined by the range $28-32^{\circ} \mathrm{W}$ longitude and $-2^{\circ}$ to $+5^{\circ} \mathrm{N}$ latitude range (20 June 2008 at 15:45 UTC). The pixel resolution is $3.2 \times 3.1 \mathrm{~km}^{2}$ at $10.8 \mu \mathrm{m}$ wavelength and the temperature colour scale is indicated on the right side of the figure. The quasi-collocated CALIPSO track at 15:43 UTC is superimposed on the satellite images. The time lag between CALIOP and SEVIRI (CALIOP - SEVIRI) amounts to $-2 \mathrm{~min}$ at $-2^{\circ} \mathrm{N}$ and +7 min at $5^{\circ} \mathrm{N}$.

Figure $3 \mathrm{c}-\mathrm{g}$ represent the evolution of retrieved parameters from SEVIRI observations along the CALIPSO track, namely: the brightness temperature in the IR channel at $10.8 \mu \mathrm{m}$, the optical depth, the effective radius, the differences in the brightness temperatures $(\triangle \mathrm{BT} 1)$ between the $12.0 \mu \mathrm{m}$ and $10.8 \mu \mathrm{m}$ channels and the differences in the brightness temperatures $(\triangle \mathrm{BT} 2)$ between the $6.2 \mu \mathrm{m}$ and $10.8 \mu \mathrm{m}$ channels. The inversion technique of the SEVIRI spectral data has been described by Bugliaro et al. (2011) for the retrieval of the cloud properties (optical thickness, effective radius, cloud water path, thermodynamic phase, top height, etc.). For validation purposes, this technique can provide retrieved cloud products along polar orbiting satellite overpasses by navigating the tracks within the satellite coordinates. In this study, ice crystal optical properties from Baum et al. (2005a, b) have been used.

According to the temperature colour scale, the blue areas in Fig. 3b roughly define the cloud clusters. The analysis of the images in Fig. 3a and b clearly show an active mesoscale convective system linked to the intertropical convergence zone (ITCZ) usually found in the considered area $\left(2^{\circ} \mathrm{N}\right.$ latitude) in June (Xie and Carton, 2004). The pixels representing the coldest areas retrieved are at $197 \mathrm{~K}\left(-76^{\circ} \mathrm{C}\right.$, see Fig. 3c) with the largest optical depths (see Fig. 3d, with 100 being the upper limit of the SEVIRI optical thickness retrieval), indicative of active updraft producing new cells at the tropopause region. Note that Fig. 3 displays an overview of the cloud situation, and that in the following we shall focus our study on the cloud cluster located between $0^{\circ}$ and $3^{\circ} \mathrm{N}$ latitude (the cluster located on the right of Fig. 3 is beyond the scope of this paper).

Differences between the brightness temperatures at 12.0 and $10.8 \mu \mathrm{m}(\Delta \mathrm{BT} 1)$ (see Fig. 3f) show values close to 0 at the latitude of the convective cell, indicative of large cloud optical depths (as seen in Fig. 3d) or the occurrence of 


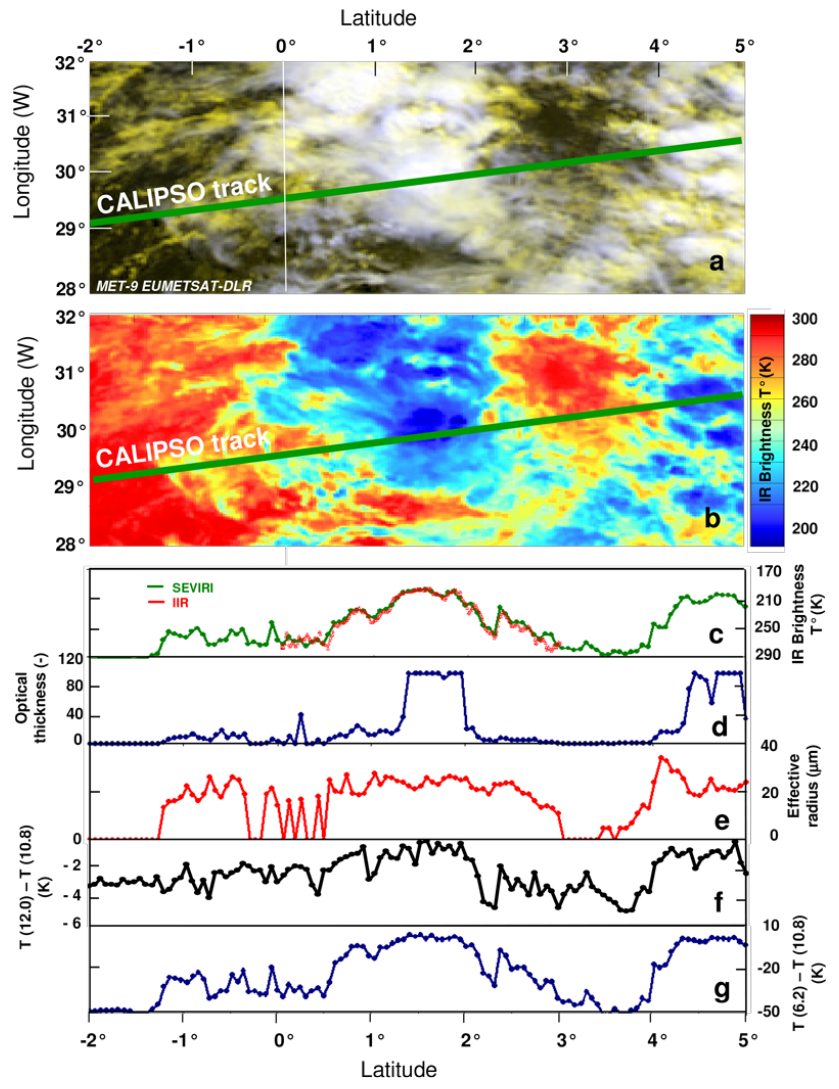

Fig. 3. MET-9/SEVIRI observations on 20 June 2008 at 15:45 UTC. (a) False colour composites from SEVIRI data and (b) brightness temperature ( $10.8 \mu \mathrm{m}$ channel). The pixel resolution is $3 \times 3 \mathrm{~km}^{2}$ at $10.8 \mu \mathrm{m}$ wavelength and the temperature colour scale is indicated on the right side of the figure. The quasi-collocated CALIPSO track at 15:43 UTC is superimposed on the satellite images. (c-g) Retrieved parameters from SEVIRI observations along the CALIPSO track, namely brightness temperature in the IR channel at $10.8 \mu \mathrm{m}$, optical depth, effective radius, differences in the brightness temperatures $(\triangle \mathrm{BT} 1)$ between the $12.0 \mu \mathrm{m}$ and $10.8 \mu \mathrm{m}$ channels and differences in the brightness temperatures ( $\triangle \mathrm{BT} 2$ ) between the $6.2 \mu \mathrm{m}$ and $10.8 \mu \mathrm{m}$ channels. Brightness temperature from the IIR imaging radiometer is superimposed on the SEVIRI retrieved temperature in (c).

large crystals. The differences in the brightness temperatures ( $\triangle \mathrm{BT} 2$ ) between the $6.2 \mu \mathrm{m}$ and $10.8 \mu \mathrm{m}$ SEVIRI channels (see Fig. $3 \mathrm{~g}$ ) give information about what most likely occurred on the tropopause level. Because the $6.2 \mu \mathrm{m}$ channel is more sensitive to water vapour absorption than the $10.8 \mu \mathrm{m}$ channel, a positive $\triangle \mathrm{BT} 2$ difference means that the cloud overshoots the tropopause (Chaboureau et al., 2007). Results in Fig. $3 \mathrm{~g}$ reveal that the $\triangle \mathrm{BT} 2$ differences are quite small $( \pm 2 \mathrm{~K})$ in the maximum-altitude areas of the clouds, and are located between $1.3^{\circ} \mathrm{N}$ and $1.9^{\circ} \mathrm{N}$ latitude. Therefore the active cloud cells do not overshoot the tropopause near the CALIPSO overpass. CALIOP profiles (see Fig. 4b next section) reveal apparent blow-off cirrus due to gravity

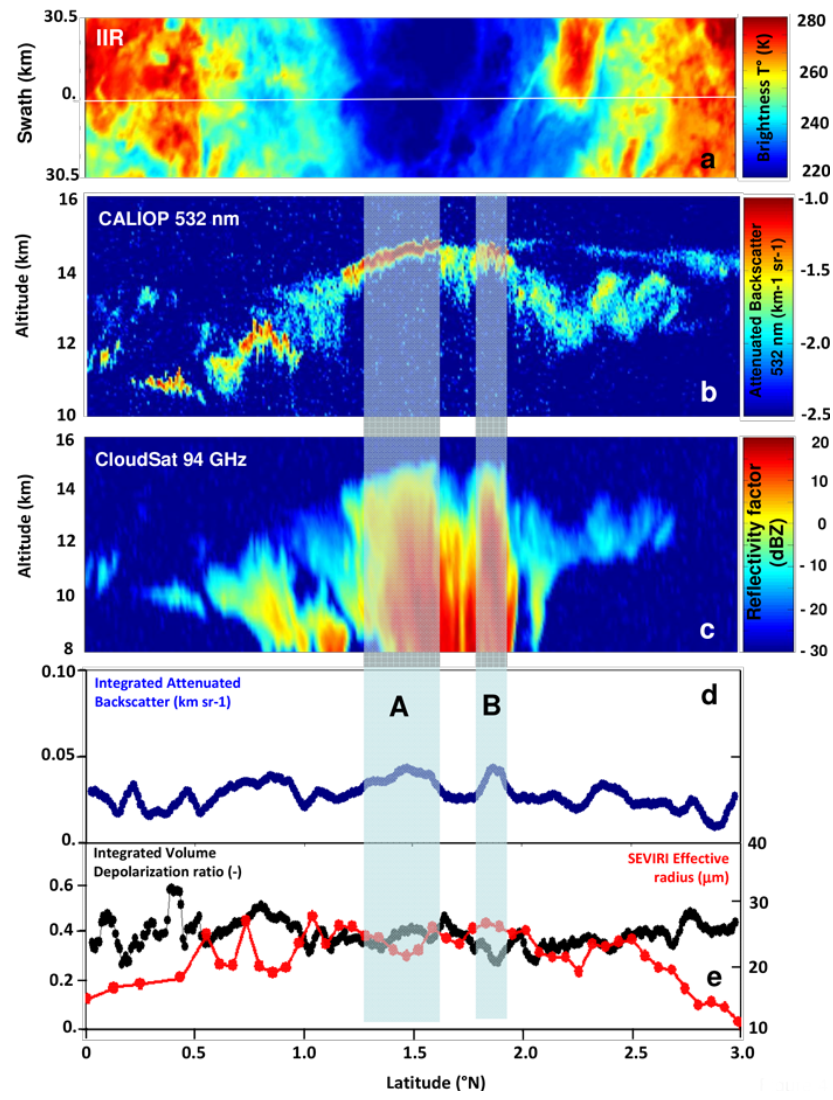

Fig. 4. As Fig. 1, but for the cloud system of 20 June 2008 (15:43 UTC). Shaded areas indicate the active parts (A and B) of the MCS. The effective radius retrieved from SEVIRI data are superimposed on the curve in (c).

wave breaking that may transport water vapour through the tropopause (Wang, 2007). Note that such cirrus clouds are not detected by the CloudSat radar (see Fig. $4 \mathrm{c}$ next section); this indicates the presence of small ice particles no larger than $30 \mu \mathrm{m}$ in diameter.

To summarize, the analysis of the MET-9/SEVERI observations reveals pixels along the CALIOP/CloudSat track that represent very cold areas. This is the location of the active updraft that produces new cloud material in the upper troposphere. In the next section we analyse the CALIOP/CloudSat data in the same way as previously described in Sect. 3 for the continental isolated convective cloud (26 May 2007).

\subsection{Analysis of CALIOP backscatter and CloudSat data}

With the same presentation as in Fig. 1a-e, Figure 4a-e display the IIR brightness temperature image, the vertical profiles of the attenuated backscatter coefficient from CALIOP (log scale) and the equivalent reflectivity factor from CloudSat, along the latitude range from $0^{\circ}$ to $3^{\circ} \mathrm{N}$ on 20 June 2008 at 15:43 UTC. The integrated attenuated backscatter and the integrated volume depolarization ratio along the 
latitude are also depicted in Fig. 4d and e, respectively. The results show that the system reached a maximum altitude of about $15700 \mathrm{~m}$ at two distinct locations (at $\sim 1.40^{\circ} \mathrm{N}$ and $\sim 1.90^{\circ} \mathrm{N}$ latitudes; see shaded areas labelled $\mathrm{A}$ and $\mathrm{B}$, respectively). These two cloud areas are characterized by neartop cloud backscatter anomalies where the IIR instrument measures coldest brightness temperatures (down to $198 \mathrm{~K}$, $-75^{\circ} \mathrm{C}$ ) at $10.6 \mu \mathrm{m}$. For comparison purposes the IIR brightness temperatures along the track have been superimposed on the SEVIRI retrieved values in Fig. 3c. The two IR brightness temperatures fit remarkably well all along the cloud cluster overpass (within $\pm 1 \mathrm{~K}$ deviation) despite the different spatial resolutions; this indicates a good collocation of SEVIRI and the polar orbiting satellite data.

The integrated attenuated backscattering coefficient (Fig. 4d) peaks in the two shaded cloud areas defined above (parts A and B) to $0.043 \mathrm{sr}^{-1}$, a similar value to those reported by PL in tropical MCS (i.e. $0.055 \mathrm{sr}^{-1}$ ). Note that a similar feature is observed between $0.6-0.9^{\circ}$ but for a much lower cloud. In the surrounding outflow cirrus, the typical value is about $0.03 \mathrm{sr}^{-1}$. The integrated volume depolarisation ratio $\left(\Delta_{\mathrm{e}}\right.$, see Fig. $\left.4 \mathrm{e}\right)$ changes concurrently with the largest values of the integrated backscattering ratio, with a value increasing up to 0.44 in cloud part $\mathrm{A}$ and decreasing down to 0.29 in part B, whereas a mean value of 0.38 is observed in the surrounding cloud clusters. Sharp $\Delta_{\mathrm{e}}$ increases are observed at the northern fringes of parts $\mathrm{A}$ and $\mathrm{B}$ which reveal significant contrasts in microphysical properties, as will be discussed below. As for the 26 May 2007 situation described above, the cloud properties derived from CALIOP measurements are summarized in Table 1. Compared to the values found in the isolated continental convective cloud, the isotropic backscatter-to-extinction ratio $\left(k_{\mathrm{e}}\right)$ remains comparable to values obtained by PL over the Pacific Ocean warm pool system, but is significantly lower than in the previous CIRCLE2 case (0.65 versus 1.06$)$ as is the integrated depolarization ratio $\left(\Delta_{\mathrm{e}}\right)(0.44$ and 0.29 versus 0.54$)$. There is an additional difference concerning part B since $\Delta$ decreases where the backscatter peaks (see Fig. $4 \mathrm{~d}$ and e).

The value of $k_{\mathrm{e}}$ of 0.65 (Table 1) could be compared with theoretical values for randomly oriented hexagonal solid columns (0.6-0.9) provided by Takano and Liou (1995). For increasing $\Delta$ values in cloud part $\mathrm{A}$, hexagonal column shaped ice crystals may be the dominant particles, which would explain the observed integrated depolarization ratio $\left(\Delta_{\mathrm{e}}=0.44\right)$ according to the calculations by Takano and Liou (1995) and Noël et al. (2004) - i.e. 0.55 and 0.44, respectively. By contrast, a significant $\Delta$ decrease $(-0.09$, see Table 1$)$ is observed in part B of the cloud system. Low $\Delta_{\mathrm{e}}$ values (0.29) may indicate hexagonal plates rather than columns (see Fig. 1 in Noël et al., 2004). As suggested by $\mathrm{PL}$, a larger number of droxtal particles may explain the low integrated depolarization ratio in the peak activity areas.

A qualitative analysis of SEVIRI images animation (every $15 \mathrm{~min}$, not show here) shows that the system developed with a weak advection in the period from 14:00 to 17:00 UTC, and that the development of new cells occurred mainly on the north side of the cluster. Therefore, part B of the cloud system (see Fig. 4) was likely a new, fresh, growing cell compared to the oldest cloud (part A), which has a larger horizontal extent (i.e. $\sim 40 \mathrm{~km}$ versus $\sim 20 \mathrm{~km}$ ). Consequently, neartop cloud properties in terms of integrated depolarization ratios may indicate signatures of microphysical characteristics according to the cloud stage evolution. This feature is confirmed by the effective radius retrieved from SEVIRI data (see superimposed curve in Fig. 4e). A larger $R_{\text {eff }}(27 \mu \mathrm{m})$ is observed in the fresh cloud (part B), whereas a smaller effective radius $(22 \mu \mathrm{m})$ is found in part $\mathrm{A}$. It is interesting to note that much smaller ice particles have been retrieved $\left(R_{\text {eff }} \sim 15 \mu \mathrm{m}\right)$ near the top of the isolated continental convective cloud described in Sect. 3 (see also Fig. 6 in GA). This is a consistent feature regarding maritime/continental cloud microphysical properties (see among others Rosenfeld and Lensky, 1998). Finally, even in the likely fresh convective cell (part B), the CloudSat radar reflectivity profile (with the corresponding extinction coefficient) at $1.840^{\circ} \mathrm{N}$ latitude (see Fig. 5) indicates the presence of ice particles large enough to be detected up to the cloud top identified by lidar. A similar feature is observed in part A.

To summarize, the backscatter anomalies reported on 20 June 2008 in the oceanic tropical MCS confirm the observations by PL, but reveal significant differences of near-top cloud properties to those observed in the continental isolated convective system (CIRCLE2, 26 May 2007 situation). In order to explain the decrease of the depolarization ratio, PL assume a greater preponderance of frozen droplets or small ice crystals in the peak activity area. This hypothesis is based on previous works on subtropical and tropical convection (Heymsfield et al., 2005a, 2006) and even in maritime tropical convective updrafts (Heymsfield et al., 2009). Many small particles of frozen droplets or ice crystals (possibly droxtals, Yang et al., 2003) are mixed with less numerous larger ice crystals with different shapes (hexagonal columns, plates, irregular, see Noël at al., 2004). The smaller ice crystals contribute to high CALIOP extinction values (see GA) whereas CloudSat, which is sensitive to large particles only, reveals the presence of larger ice crystals lofted to the cloud top. In other words, the CALIPSO and CloudSat satellites overpassed the most active MCS region with likely the strongest updrafts. This region corresponds to the coldest temperatures and with maximum cloud top altitudes derived from MET9/SEVIRI data.

\section{Retrieved MCS cloud properties at usual cruise altitudes of commercial aircraft}

In this section the cloud ice water content (IWC) and effective radius $\left(R_{\text {eff }}\right)$ retrieved with both the CloudSat 2B-IWC algorithm (Benedetti et al., 2003, called C2B hereafter) and 


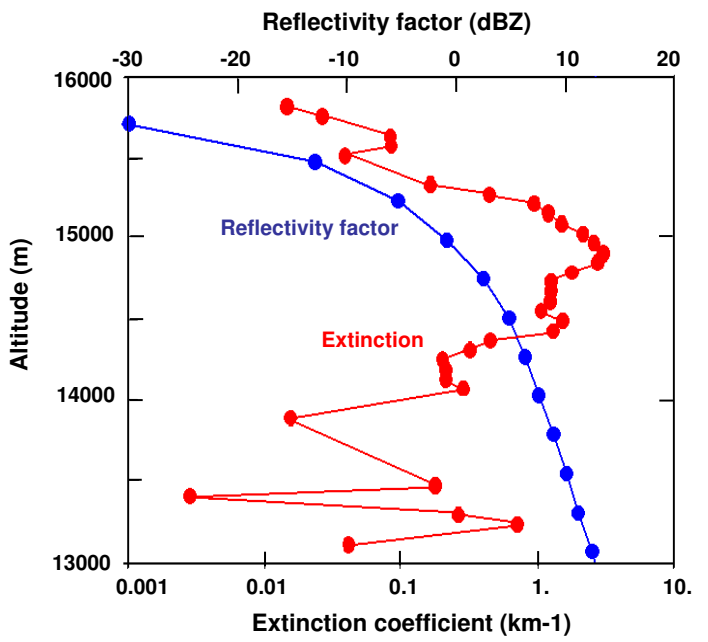

Fig. 5. Same as Fig. 2, but for profiles obtained at the centre of part B of the convective cell $\left(1.840^{\circ} \mathrm{N}\right.$, see Fig. 4) for the 20 June 2008 MCS.

the DARDAR (raDAR/liDAR, called DAR hereafter) icecloud products (Delanoë and Hogan, 2008, 2010) are analysed.

The $\mathrm{C} 2 \mathrm{~B}$ retrieval is designed to use CloudSat Radar (CPR) radar reflectivity and visible optical depth if both data streams are available. The source for the visible optical depth is the MODIS (Moderate Resolution Imaging Spectroradiometer) instrument on the Aqua platform. The retrieval technique described in detail by Benedetti et al. (2003) was adapted from the study by Austin and Stephens (2001). This technique is based on minimization of a cost function which calculates the distance between the model-derived and the observations variables. The forward model is assumed to describe cirrus size spectra via a modified gamma size distribution (Stephens et al., 1990). The model equivalent radar reflectivities in the Rayleigh regime and the visible optical depth are computed using analytical expressions from two parameters of the size distribution, i.e. the mean size and the number concentration. The radar reflectivities are corrected for non-Rayleigh and density effects. When ice particles are sampled, a constant correction factor $(K)$ is introduced since radar reflectivity is conventionally defined with respect to water (equivalent radar reflectivity). The factor $K$ introduces the implicit assumption that the density of ice crystals is constant, and is prescribed by size-density relationships proposed by Brown and Francis (1995) and Matrosov (1999).

The DAR technique is a synergistic product, combining the CloudSat radar and CALIOP lidar measurements. This synergy retrieval is based on the optimal estimation framework (Rodgers, 2000); it allows one to retrieve ice cloud properties seamlessly while accounting for instrumental random errors. For instance, cloud properties are retrieved when lidar and/or radar measurements are available. The main advantage of this method is to characterize cloud properties of

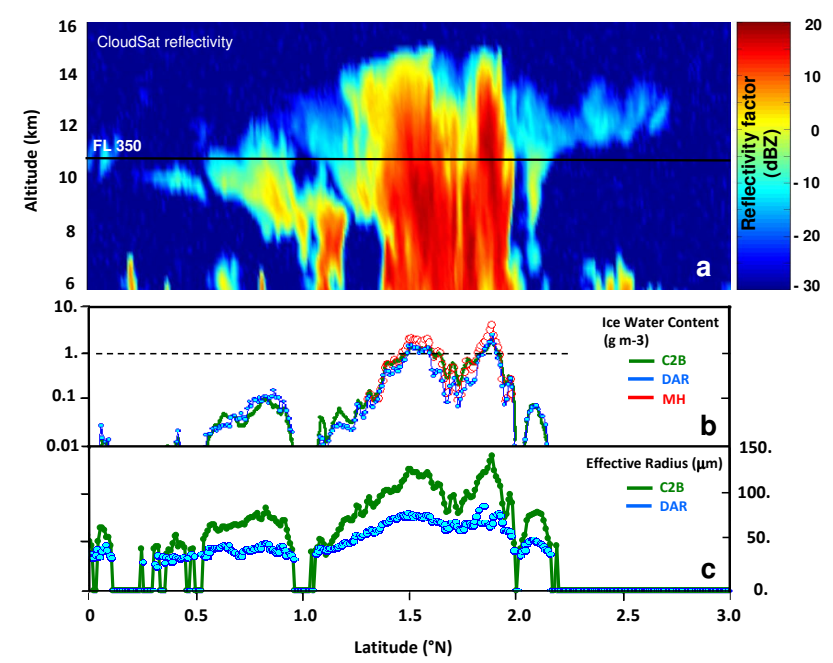

Fig. 6. (a) Vertical profiles of the equivalent reflectivity factor from CloudSat. (b, c) Variations of the retrieved IWC (log scale) and effective radius, respectively, along the $10700 \mathrm{~m}$ level. IWC is retrieved from both the CloudSat 2B-IWC (C2B, green curve) and DARDAR (DAR, blue symbols) algorithms and from the relationship proposed by Matrosov and Heymsfield (2008) (MH; red symbols for reflectivities $>0 \mathrm{dBZ}$ ).

types ranging from thin cirrus (using lidar when radar sensitivity is limited) to very deep ice clouds (using radar when lidar is extinguished). In the optimal estimation framework a forward model is required to convert cloud properties in radar and lidar measurements. One starts with a first guess of the cloud properties, for example a constant value of extinction and number concentration. The values are converted into synthetic measurements, which are compared to the real measurements. Then, using an iteration process, one minimizes the differences (in the least square sense) between real and simulated measurements. The forward model assumes that the particles are mainly aggregates (adapted from Brown and Francis, 1995; Mitchell, 1996) and their distribution is represented with the normalized particle size distribution (PSD) approach (Delanoë et al., 2005). Mass-size relationships are identified accordingly (Delanoë and Hogan, 2008). This technique allows one to link, in an efficient way, the different moments of the PSD, and therefore the cloud properties, to the measurements. Therefore cloud parameters such as IWC and $R_{\text {eff }}$ are retrieved at each radar and/or lidar gate $(60 \mathrm{~m}$ vertical resolution).

\subsection{Ice water content}

In Fig. 6a, the vertical profiles of equivalent reflectivity factor from CloudSat along the orbit are displayed again (20 June 2008, 15:43 UTC) in order to facilitate the discussion of the results. We recall that the resolution of the pixels is $250 \mathrm{~m}$ (vertical) $\times 2500 \mathrm{~m}$ (horizontal). The black line in Fig. 6a indicates the $10700 \mathrm{~m}$ altitude which corresponds 


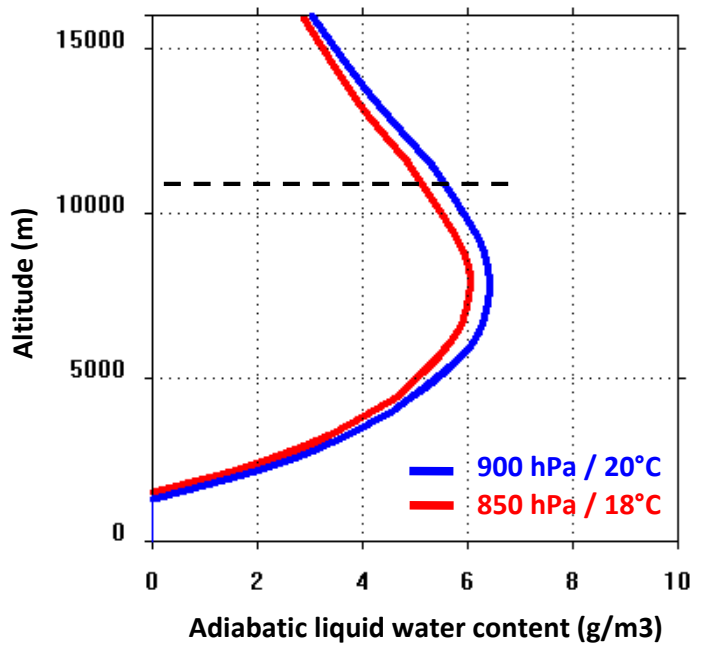

Fig. 7. Profiles of the theoretical adiabatic liquid water content (LWC), assuming the most likely thermodynamic properties of the cloud base $\left(900 \mathrm{hPa} / 20^{\circ} \mathrm{C}\right.$ and $\left.850 \mathrm{hPa} / 18^{\circ} \mathrm{C}\right)$ obtained from the CALIPSO additional meteorological parameters.

to the usual flight level (FL 350 or 35000 feet) of commercial aircraft. Figure $6 \mathrm{~b}$ displays the variation of the $\mathrm{C} 2 \mathrm{~B}$ and DAR-retrieved IWCs at this level. Due to the log-scale presentation, the differences between the two satellite retrievals are not well evidenced but they will be detailed below (Fig. 8). The main feature of the results can be summarized as follows: the cluster extends from a latitude of about $0.5^{\circ} \mathrm{N}$ to $2.5^{\circ} \mathrm{N}(\sim 220 \mathrm{~km})$ with the core of the system observed between a latitude of $1.5^{\circ} \mathrm{N}$ and $2.0^{\circ} \mathrm{N}(\sim 55 \mathrm{~km})$. As already discussed in the previous section, ice particles are large enough to be detected by CloudSat, with significant IWC up to the top of cloud core observed concurrently with backscatter anomalies and the lowest temperatures (see Fig. 5). Indeed, reflectivities up to $3 \mathrm{dBZ}$ and subsequent IWC of $\sim 0.5 \mathrm{~g} \mathrm{~m}^{-3}$ are observed $1000 \mathrm{~m}$ below the cloud top. At the $10700 \mathrm{~m}$ level, IWCs remain quite low $\left(\sim 0.1 \mathrm{~g} \mathrm{~m}^{-3}\right)$ until a latitude of $1.3^{\circ} \mathrm{N}$, and then significantly increases in the cloud core along the considered altitude. IWC values remain larger than $1.0 \mathrm{~g} \mathrm{~m}^{-3}$ for $55 \mathrm{~km}$ (which represents a flight duration of about 4:30 min with an airspeed of Mach 0.80) and peaks at 2.0-2.5 $\mathrm{g} \mathrm{m}^{-3}$. Because the horizontal resolution of retrieved products is $2.5 \mathrm{~km}$, higher IWC values on smaller scales may be encountered. The cloud particles are likely to be ice crystals since the temperature of $-40^{\circ} \mathrm{C}$ at $10700 \mathrm{~m}$ (CALIPSO additional meteorological parameters) is below the temperature for which the supercooled liquid water droplets freeze by homogeneous nucleation $\left(-37^{\circ} \mathrm{C}\right)$.

Figure 7 displays the theoretical adiabatic liquid water content (LWC) assuming the most likely thermodynamic properties of the cloud base $\left(900 \mathrm{hPa} / 20^{\circ} \mathrm{C}\right.$ or $850 \mathrm{hPa} / 18^{\circ} \mathrm{C}$ obtained from CALIPSO additional meteorological parameters). A maximum adiabatic $\mathrm{LWC}$ of $\sim 5.0 \mathrm{~g} \mathrm{~m}^{-3}$ is found at

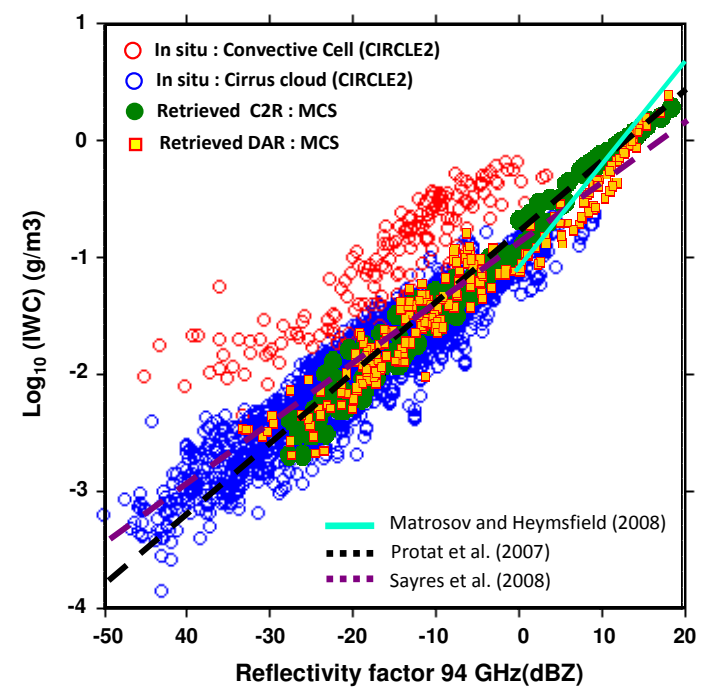

Fig. 8. Retrieved IWC- $Z$ relationship obtained from both the CloudSat 2B-IWC (green symbols) and DARDAR (yellow symbols) algorithms for $10700 \mathrm{~m}$ (FL350) in the MCS system on 20 June 2008. IWC $-Z$ relationships obtained from in situ observations on 26 May 2007 for continental isolated convective cloud and the outflow cirrus observations are red and blue symbols, respectively. The relationships proposed by Matrosov and Heymsfield (2008), Protat et al. (2007) and Sayres et al. (2008) are reported.

$10700 \mathrm{~m}$ altitude. The retrieved high ice water contents (up to $2.0-2.5 \mathrm{~g} \mathrm{~m}^{-3}$ ) are smaller than the maximum value of the theoretical adiabatic LWC at $10700 \mathrm{~m}\left(\sim 5.0 \mathrm{~g} \mathrm{~m}^{-3}\right)$ which could be explained by entrainment of dry environmental air around the cluster and/or by precipitation removing significant amounts of cloud water.

However, it is well-known that cloud ice content estimates can have uncertainties as large as a factor of 2 (see, among others, Heymsfield et al., 2005b). For instance, much larger IWC is obtained (see superimposed red points on the results in Fig. 6b) with a maximum of $4 \mathrm{~g} \mathrm{~m}^{-3}$ (rather close to the adiabatic value) if we consider the relationship between $\mathrm{W}$ band radar reflectivity and ice cloud content proposed by Matrosov and Heymsfield (2008, called MH hereafter) for highreflectivity clouds. Their relationship accounts for the particle aspect ratio and for the non-sphericity of larger particles via mass-size relation assumptions.

In order to check the consistency of the results, the retrieved IWC $-Z$ relationships obtained at $10700 \mathrm{~m}$ in the MCS system (20 June 2008) are displayed in Fig. 8 (green and yellow symbols for $\mathrm{C} 2 \mathrm{~B}$ and DAR, respectively) together with the relationships proposed by Protat et al. (2007) from mid-latitude and tropical field campaigns, by Sayres et al. (2008) in tropical anvils during CRYSTAL-FACE (dashed lines) and by Matrosov and Heymsfield (2008, unbroken line) discussed above.

A careful examination of the retrieved IWC dispersion shows that $\mathrm{C} 2 \mathrm{~B}$ overestimates DAR by up to $50 \%$ for 
IWC less than $0.6 \mathrm{~g} \mathrm{~m}^{-3}$ as already discussed in Protat et al. (2010a) and Delanoë et al. (2013). Consequentially, for larger IWC, the agreement between the two methods is within $\pm 25 \%$. The retrieved IWC $-Z$ scatterplots (C2B and DAR) are roughly consistent with experimental relationships from Protat et al. (2007) and Sayres et al. (2008) with a maximum IWC of $2.0-2.5 \mathrm{~g} \mathrm{~m}^{-3}$ for a radar reflectivity of $18 \mathrm{dBZ}$. Larger discrepancies are observed when considering the $\mathrm{MH}$ relationship in regions of radar reflectivity at $94 \mathrm{GHz}$ exceeding about $5 \mathrm{dBZ}$ with a maximum retrieved IWC of $4.0 \mathrm{~g} \mathrm{~m}^{-3}$ at $18 \mathrm{dBZ}$. Discussing their experimental relationship, $\mathrm{MH}$ emphasize that the data scatter for IWC $-Z$ relationship becomes progressively smaller as reflectivity increases (see their Fig. 4). The same scatter plot convergence at larger values is observed for different data sets originating from various cloud types and geographical regions. MH concluded that the derived relationships are likely to be applicable to a wide variety of precipitating cloud systems, although significant differences in cloud properties could be expected between MCS and continental clouds because of different aerosol inputs and dynamical properties (weaker updrafts in maritime MCS, Mason et al., 2006), etc.

Therefore, the relationships obtained from in situ observations related to the outflow cirrus observations and the continental isolated convective cloud obtained on 26 May 2007 (CIRCLE2, blue and red symbols, respectively) have been reported in Fig. 8. Despite large uncertainties about quantitative values of microphysical parameters (IWC, $R_{\text {eff }}, Z$, etc.) derived from in situ instruments (see below), the results in Fig. 8 show that the retrieved IWC $-Z$ relationships $(\mathrm{C} 2 \mathrm{~B}$ and DAR) roughly fit the in situ observations (blue symbols) related to outflow cirrus (for $Z<10 \mathrm{dBZ}$ ). This is a consistent feature since the retrieving techniques use forward model assumptions mainly based on experimental results obtained in anvils and/or outflow cirrus.

By contrast, for the core of the convective cell (red symbols in Fig. 8), it is found that the IWC- $Z$ relationship would produce much larger IWC (by about one order of magnitude) than the more standard relationships. This feature is of crucial importance for aircrafts and may be explained as follows.

i. The in situ observations performed very near the top of the core of the overshooting cell revealed numerous small chain-like aggregate crystals (leading to backscatter anomalies), whereas larger bullet-rosette particles were observed in the adjacent cirrus. Therefore the large differences between the red and blue IWC $-Z$ in situ measurements in Fig. 8 are due to the different mass-size relationships related to the subsequent ice particle shapes (see Fig. 9 in GA). This result needs to be confirmed by additional observations because only a few data are available in such conditions (Stith et al., 2013).

ii. Significant shortcomings occur in IWC and $Z$ derivations from in situ measurements; these are mainly due

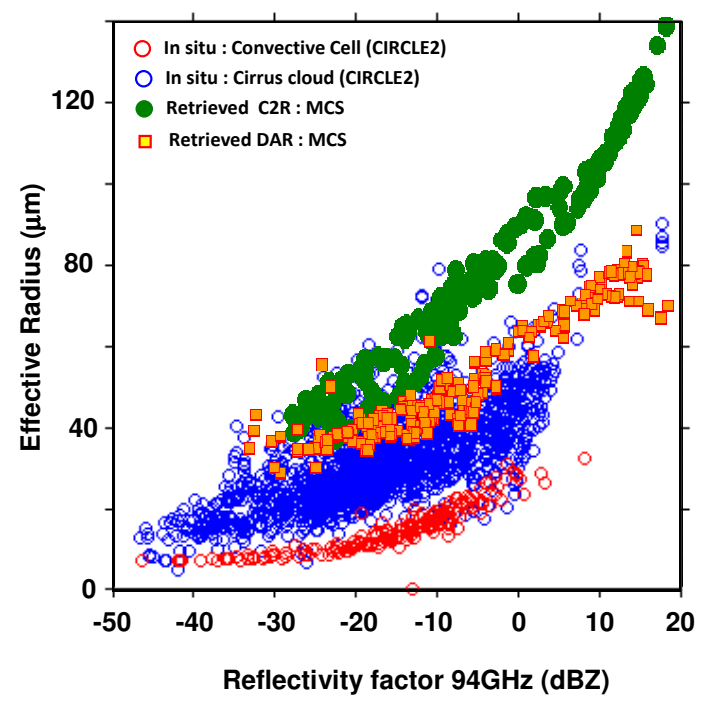

Fig. 9. Same as Fig. 8. $R_{\mathrm{eff}}-Z$ relationships.

to particle aspect ratio and ice density effects which are poorly described and non-sphericity via mass-size relationship assumptions. As discussed by Heymsfield et al. (2008) by testing 10 retrieval methods, IWC retrievals in regions of radar reflectivity at $94 \mathrm{GHz}$ exceeding about $5 \mathrm{dBZ}$ are subject to uncertainties of $50 \%$. They are explained by the use of the Rayleigh approximation (e.g. assuming that the particle size is much smaller than the wavelength $-3.2 \mathrm{~mm}$ at $94 \mathrm{GHz}$ -) at high reflectivities in some of the algorithms and the differences in the way non-spherical particles and Mie effects are considered.

iii. Systematic errors regarding in situ measurements due to the contamination by the shattering of larger ice crystals on the probe tips may result in artificially high concentrations of small ice crystals with subsequent high extinction coefficients and low effective radii (see, for instance, Korolev and Isaac, 2005; Lawson et al., 2006; Heymsfield, 2007; Protat et al., 2010b).

The great variability of the results in Fig. 8 (in situ observations, retrieved values, experimental relationships) lead to the conclusion that there are combined shortcomings in the derivation of the microphysical parameters which seriously hamper the quantitative interpretation of the results, particularly in the denser part of the overshooting cell. At the time of this study, IWC- $Z$ relationships are not yet available to describe the core of deep various (continental/maritime) MCS with the use of new generation of cloud instruments. These instruments have specially designed tips and electronics that may now provide much more accurate in situ measurements (see for instance, Korolev et al., 2013). 


\subsection{Effective radius}

Figure 6c displays the variations of the C2B-retrieved effective radius $\left(R_{\text {eff }}\right)$ and DAR-retrieved $\left(R_{\text {eff }}\right)$ along the latitude at the $10700 \mathrm{~m}$ level. It is found that the C2B effective radii are systematically about $30 \%$ larger than the DAR ones. DAR effective radii fluctuate between 40 and $55 \mu \mathrm{m}$ up to the latitude of $1.3^{\circ} \mathrm{N}$, then increase in the cloud core to about $60 \mu \mathrm{m}$ and reach $80 \mu \mathrm{m}$ concurrently with the highest IWC values (see Fig. 6b). The comparisons with in situ measurements in Fig. 9 (with the same representation and symbols as in Fig. 8) show that the $\mathrm{C} 2 \mathrm{~B}$ retrieved effective radii are a factor of about 2 larger than values obtained for the outflow cirrus observations (blue symbols). DAR effective radii are distributed closer to the in situ observations. Several hypotheses may explain these differences:

i. Accurate in situ measurements of particle effective radius are not available in MCS clusters. Such data obtained with a new generation of instruments (see above) will improve the comparisons of the retrieved $R_{\text {eff }}$ within the IWC $-Z$ relationships.

ii. As discussed above, in situ measurements may be contaminated by the shattering of larger ice crystals on the probe tips, resulting in systematic errors with artificially high concentrations of small ice crystals with artificially low effective radii. As discussed in GA, there are still large uncertainties regarding the magnitude of the contribution of these small ice crystals to the bulk microphysical properties.

iii. Large errors may arise from uncertainties of the forward model used for the inversion techniques (Benedetti et al., 2003). Among the factors that may contribute to these errors is the choice of size distribution and related parameters. If such a distribution is completely unrepresentative of real clouds, this can degrade the accuracy of the solution. For instance, bimodal spectra are often observed in warm thick midlatitude cirrus (Ivanova et al., 2001) making the assumption of a monomodal gamma distribution unrealistic. Likewise, a worse parameter-description of small ice crystals could lead to oversized retrieved particles. Uncertainties due to non-sphericity of the ice crystals and ice densities (Mitchell et al., 1990) could also be important.

\section{Discussion and conclusions}

Two complementary case studies have been presented to analyse the properties of convective systems in the region where strong cloud-top backscatter anomalies are observed as reported by PL. These anomalies are observed for the first time in an isolated continental convective cloud over Germany during the CIRCLE2 experiment (26 May 2007).
Quasi-collocated in situ observations confirm that these regions represent the most active and dense convective cloud parts with likely the strongest core updrafts and unusually high values for the concentration of small ice particles, extinction and ice water content. Moreover, the theoretical shape derived from CALIOP data interpretation may roughly fit with the observed dominant ice particle shape (chain-like aggregate).

Similar spaceborne data are observed in a maritime mesoscale cloud system (MCS) on the 20 June 2008 located off the Brazilian coast between $0^{\circ}$ and $3^{\circ} \mathrm{N}$ latitude. The analysis of the MET-9/SEVIRI observations reveals pixels along the collocated CALIPSO/CloudSat track (a time lag of max $3 \mathrm{~min}$ ) that represent cold areas. This is the area of active updraft that produces new dense cloud material in the upper troposphere. This feature is confirmed by concurrent near cloud-top backscatter anomalies from CALIOP data and CloudSat reflectivities. Near-top cloud properties in terms of integrated depolarization ratios $(\Delta)$ may indicate signatures of microphysical characteristics. They are found to be significantly different from those observed in the continental isolated convective cloud. Indeed, SEVIRI retrievals confirm much smaller ice particles near the top of the isolated continental convective cloud, i.e. $R_{\text {eff }} \sim 15 \mu \mathrm{m}$ versus 22 $27 \mu \mathrm{m}$ in the MCS. Near-top cloud properties may also indicate signatures of microphysical characteristics according to the cloud-stage evolution, as revealed by SEVIRI images, to identify the development of new cells within the MCS cluster. For instance, randomly oriented solid columns may explain increasing $\Delta$ values in older cloud cells. By contrast, a significant $\Delta$ decrease is observed in new dense clouds that may indicate hexagonal plates rather than columns and a greater number of droxtal particles in the peak activity areas (Platt et al., 2011). This feature is confirmed by the effective radius retrieved from SEVIRI data. Larger effective radii $(27 \mu \mathrm{m})$ are observed in the fresh cloud whereas smaller effective radii are found in older cell.

CloudSat and CALIPSO observations are used to describe the cloud properties which likely prevailed in the most active MCS region with the strongest updrafts at the usual cruise altitudes of commercial aircraft ( $10700 \mathrm{~m} / \mathrm{FL} 350$ or above). Cloud ice water content (IWC) and effective radii have been estimated from the satellite observations using both the CloudSat 2B-IWC and DARDAR retrieval techniques. At the considered altitude, IWC significantly increases in the cloud core concurrently with backscatter anomalies and the presence of the lowest temperatures. IWC values remain larger than $1.0 \mathrm{~g} \mathrm{~m}^{-3}$ for $55 \mathrm{~km}$ (which represents a flight duration of about 4:30 min with an airspeed of Mach 0.80) and peaks at $2.0-2.5 \mathrm{~g} \mathrm{~m}^{-3}$ or even more $\left(4 \mathrm{~g} \mathrm{~m}^{-3}\right)$, according to different IWC $-Z$ relationships. This range of deviation illustrates shortcomings in both IWC retrievals for high-reflectivity clouds (due to Rayleigh approximation, non-spherical ice particles, multiple scattering and Mie effects, see Battaglia et al., 2011) and IWC estimates from in situ measurements 
(due to particle aspect ratio effects and non-sphericity for large particles via mass-size relationship assumptions). Because the pixel horizontal resolution of retrieved products is $2.5 \mathrm{~km}$, higher IWC values at smaller scales could be encountered. The retrieved IWC $-Z$ relationships from the CloudSat 2B-IWC and DARDAR retrieval techniques are roughly consistent with in situ observations in the outflow cirrus region (CIRCLE2 data). It should be noticed that at the considered altitude, the temperature $\left(-40^{\circ} \mathrm{C}\right)$ is lower than the temperature at which the supercooled liquid water droplets freeze by homogeneous nucleation $\left(-37^{\circ} \mathrm{C}\right)$, and the cloud particles are likely pure ice crystals. The vertical velocity in the active MCS region may lead to a rapid freezing of the droplets, leading in turn to a large number of small-sized particles.

The retrieved effective radius (DARDAR $R_{\text {eff }}$ ) increases in the cloud core to about $60 \mu \mathrm{m}$ and reaches $80 \mu \mathrm{m}$ concurrently with the highest IWC values. The comparisons with in situ observations in cirrus ice clouds show systematically

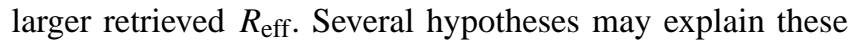
differences:

i. Systematic errors regarding in situ measurements due to the contamination by the shattering of larger ice crystals on the probe tips, resulting in artificially high concentrations of small ice crystals with high extinction coefficients and low effective radii.

ii. Large errors may arise from uncertainties in the forward model used for the CloudSat inversion. Among the factors that may contribute to these errors is the choice of size distribution and parameters related to this size distribution. Likewise, a worse parameterdescription of small ice crystals could lead to oversized retrieved particles, and uncertainties due to nonsphericity of the ice crystals and ice densities could also be important.

To conclude, quite high IWC (within a range between from 2 to $4 \mathrm{~g} \mathrm{~m}^{-3}$ according to the specific IWC- $Z$ relationship derived from in situ measurements) could be encountered at the usual cruise altitudes of commercial aircraft. These values appear to correspond in the active MCS region to a maximum reflectivity factor of $18 \mathrm{dBZ}$ (at $94 \mathrm{GHz}$ ). Because the radar reflectivity depends on the sixth moment of the size distribution, the particle size is a critical parameter for which the measurement accuracy must be considerably improved. A new generation of cloud instruments with specially designed tips and electronics may now provide much more accurate in situ measurements (see, for instance, Korolev et al., 2013). In the same way, relevant IWC- $Z$ relationships should be obtained in order to describe the core of deep MCS. To complete this study, the analysis of radar echoes obtained simultaneously by radars at $94 \mathrm{GHz}$ and $35 \mathrm{GHz}$ (onboard radars) in ice clouds with different properties would be important to assess more relevant IWC- $Z$ relationships.
Finally, it is argued that the availability of real-time information of the kilometre-scale cloud top IR brightness temperature decrease with respect to the cloud environment would help identify MCS cloud areas with potentially high ice water content and small particle sizes to which onboard meteorological radars may not be sensitive enough in order to be able to provide timely warning. Researchers could examine this in future studies by generalizing the results from a statistical approach and by considering relevant criteria, such as optical depth and/or brightness temperature differences (see Fig. 3d and f, respectively) to identify these MCS cloud areas.

Acknowledgements. We acknowledge NASA Langley Research Atmospheric Science Data Center for the CALIPSO data, as well the CloudSat Data Processing Center at the Colorado State University as well as ICARE Centre in Lille for the CALIPSO/CloudSat data. The support of CNES is also acknowledged. SEVIRI data operationally distributed by EUMETSAT Data Centre have been processed at DLR. J.-F. Gayet is grateful to DLR for having provided a guest scientist opportunity at the Institut für Physik der Atmosphäre during this study. The authors would like to thank the three anonymous reviewers for their suggestions and helpful comments.

Edited by: G. Vaughan

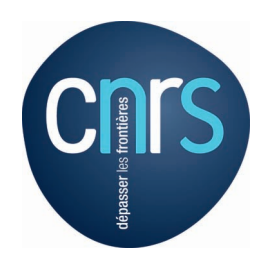

The publication of this article is financed by CNRS-INSU.

\section{References}

Austin, R. T. and Stephens, G. L.: Retrieval of stratus cloud microphysical parameters using millimeter-wave radar and visible optical depth in preparation for CloudSat: 1. Algorithm formulation, J. Geophys. Res., 106, 28233-28242, 2001.

Battaglia, A., Augustynek, T., Tanelli, S., and Kollias, P.: Multiple scattering identification in spaceborne w-band radar measurements of deep convective cores, J. Geophys. Res., 116, D19201, doi:10.1029/2011JD016142, 2011.

Baum, B. A., Heymsfield, A. J., Yang, P., and Bedka, S. T.: Bulk Scattering Properties for the Remote Sensing of Ice Clouds. Part I: Microphysical Data and Models, J. Appl. Meteor., 44, 18851895, doi:10.1175/JAM2308.1, 2005a.

Baum, B. A., Yang, P., Heymsfield, A. J., Platnick, S., King, M. D., Hu, Y.-X., and Bedka, S. T.: Bulk scattering properties for the remote sensing of ice clouds. Part II: Narrowband models, J. Appl. Meteor., 44, 1896-1911, doi:10.1175/JAM2309.1, 2005b.

Benedetti, A., Stephens, G. L., and Haynes, J. M.: Ice cloud microphysics retrievals from millimeter radar and visible optical depth using an estimation theory approach, J. Geophys. Res., 108, 4335, doi:10.1029/2002JD002693, 2003. 
Brown, P. R. A. and Francis, P. N.: Improved measurements of the ice water content in cirrus using a total-water probe, J. Atmos. Oceanic Technol., 12, 410-414, 1995.

Bugliaro, L., Zinner, T., Keil, C., Mayer, B., Hollmann, R., Reuter, M., and Thomas, W.: Validation of cloud property retrievals with simulated satellite radiances: a case study for SEVIRI, Atmos. Chem. Phys., 11, 5603-5624, doi:10.5194/acp-11-5603-2011, 2011.

Chaboureau, J.-P., Cammas, J.-P., Duron, J., Mascart, P. J., Sitnikov, N. M., and Voessing, H.-J.: A numerical study of tropical crosstropopause transport by convective overshoots, Atmos. Chem. Phys., 7, 1731-1740, doi:10.5194/acp-7-1731-2007, 2007.

Connolly, P. J., Saunders, C. P. R., Gallagher, M. W., Bower, K. N., Flynn, M. J., Choularton, T. W., Whiteway, J., and Lawson, R. P.: Aircraft observations of the influence of electric fields on the aggregation of ice crystals, Q. J. Roy. Meteorol. Soc., 131, 1695-1712, 2005.

Delanoë, J. and Hogan, R. J.: A variational scheme for retrieving ice cloud properties from combined radar, lidar, and infrared radiometer, J. Geophys. Res., 113, D07204, doi:10.1029/2007JD009000, 2008.

Delanoë, J. and Hogan, R. J.: Combined CloudSat-CALIPSOMODIS retrievals of the properties of ice clouds, J. Geophys. Res., 115, D00H29, doi:10.1029/2009JD012346, 2010.

Delanoë, J., Protat, A., Testud, J., Bouniol, D., Heymsfield, A. J., Banseme,r A., Brown, P. R. A., and Forbes, R. M.: Statistical properties of the normalized ice particle size distribution, J. Geophys. Res., 110, D10201, doi:10.1029/2004JD005405, 2005.

Delanoë, J., Protat, A., Jourdan, O., Pelon, J., Papazzoni, M., Dupuy, R., Gayet, J.-F., and Jouan, C.: Retrieval of polar ice cloud properties using RALI platform during POLARCAT campaign, J. Atmos. Ocean. Tech., 30, 57-73, doi:10.1175/JTECHD-11-00200.1, 2013.

Eichler, H., Ehrlich, E., Wendisch, M., Mioche, G., Gayet, J.F., Wirth, M., Emde, C., and Minikin, A.: Influence of ice crystal shape on retrieval of cirrus optical thickness and effective radius: A case study, J. Geophys. Res., 114, D19203, doi:10.1029/2009JD012215, 2009.

Garnier, A., Pelon, J., Dubuisson, P., Faivre, M., Chomette, O., Pascal, N., and Kratz, D. P.: Retrieval of cloud properties using CALIPSO Imaging Infrared Radiometer, Part 1: effective emissivity and optical depth, J. Appl. Meteorol. Clim., 51, 14071425, doi:10.1175/JAMC-D-11-0220.1, 2012.

Gayet, J.-F., Mioche, G., Bugliaro, L., Protat, A., Minikin, A., Wirth, M., Dörnbrack, A., Shcherbakov, V., Mayer, B., Garnier, A., and Gourbeyre, C.: On the observation of unusual high concentration of small chain-like aggregate ice crystals and large ice water contents near the top of a deep convective cloud during the CIRCLE-2 experiment, Atmos. Chem. Phys., 12, 727-744, doi:10.5194/acp-12-727-2012, 2012.

Heymsfield, A. J.: On measurements of small ice particles in clouds, Geophys. Res. Lett., 34, L23812, doi:10.1029/2007GL030951, 2007.

Heymsfield, A. J. and Palmer, A.: Relationship for deriving thunderstorm anvil ice mass for CCOPE storm weather estimates, J. Clim. Appl. Meteor., 25, 691-702, 1986.

Heymsfield, A. J., Miloshevich, L. M., Schmitt, C., Bansemer, A., Twohy, C., Poellot, M. R., Fridlind, A., and Gerber, H.: Homogeneous ice nucleation in subtropical and tropical convection and its influence on cirrus anvil microphysics, J. Atmos. Sci., 62, 4164, 2005a.

Heymsfield, A. J., Wang, Z., and Matrosov, S.: Improved Radar Ice Water Content Retrieval Algorithms Using Coincident Microphysical and Radar Measurements, J. Appl. Meteor., 44, 13911412, 2005b.

Heymsfield, A. J., Bansemer, A., Durden, S. L., Herman, R. L., and Bui, T. P.: Ice microphysics observations in Hurricane Humberto: Comparison with non-hurricane-generated ice cloud layers, J. Atmos. Sci., 63, 288-308, 2006.

Heymsfield, A. J., Protat, A., Bouniol, D., Austin, R. T., Hogan, R. J., Delanoë, J., Okamoto, H., Sato, K., van Zadelhoff, G.-J., Donovan, D. P., and Wang, Z.: Testing IWC retrieval methods using radar and ancillary measurements with in situ data, J. Appl. Meteor. Climatol., 47, 135-163, 2008.

Heymsfield, A. J., Bansemer, A., Heymsfield, G., and Fierro, A. O.: Microphysics of Maritime Tropical Convective Updrafts at Temperatures from -20 to $-60^{\circ} \mathrm{C}$, J. Atmos. Sci., 66, 3530 3562, 2009.

Hu, Y.: Depolarization ratio-effective lidar ratio relation: theoretical basis for space lidar cloud phase discrimination, Geophys. Res. Lett., 34, L11812, doi:10.1029/2007GL029584, 2007.

Hunt, W. H, Winker, D. M., Vaughan, M. A., Powell, K. A., Lucker, P. L., and Weimer, C.: CALIPSO Lidar Description and Performance Assessment, J. Atmos. Ocean Tech., 26, 1214-1228, doi:10.1175/2009JTECHA1223.1, 2009.

Ivanova, D., Mitchell, D. L., Arnott, W. P., and Poellot, M.: A GCM parameterization for bimodal size spectra and ice mass removal rates in midlatitude cirrus clouds, Atmos. Res., 59-60, 89-113, 2001.

Josset, D., Pelon, J., Garnier, A., Hu, Y., Vaughan, M., Zhai, P.W., Kuehn, R., and Lucker, P.: Cirrus optical depth and lidar ratio retrieval from combined CALIPSO-CloudSat observations using ocean surface echo, J. Geophys. Res., 117, D05207, doi:10.1029/2011JD016959, 2012.

Korolev, A. V. and Isaac, G. A.: Shattering during sampling by OAPs and HVPS, Part I: Snow particles, J. Atmos. Ocean Tech., 22, 528-543, 2005.

Korolev, A. V., Emery, E. F., and Creelman, K.: Modification and tests of particle probe tips to mitigate effects of ice shattering, J. Atmos. Ocean. Tech., 30, 690-708, doi:10.1175/JTECH-D-1200142.1, 2013

Lawson, R. P., Angus, L. G., and Heymsfield, A. J.: Cloud particle measurements in thunder storm anvils and possible weather threat to aviation, J. Aircraft, 35, 113-121, 1998.

Lawson, R. P., Baker, B. A., Schmitt, C. G., and Jensen, T. L.: In situ measurements of microphysical properties of mid-latitude and anvil cirrus and validation of satellite retrievals'. Paper no. TS 32.4, Proceedings of 30th International conference on remote sensing of environment, Honolulu, Hawaii, http://www. symposia.Org/proceedings.htm, 2003.

Lawson, R. P., O'Connor, D., Zmarzly, P., Weaver, K., Baker, B A., Mo, Q., and Jonsson, H.: The 2D-S (Stereo) probe: Design and preliminary tests of a new airborne, high-speed, highresolution imaging probe, J. Atmos. Ocean. Technol., 23, 14621477, doi:10.1175/JTECH1927.1, 2006

Lawson, R. P., Jensen, E., Mitchell, D. L., Baker, B., Mo, Q., and Pilson, B.: Microphysical and radiative properties of tropical 
clouds investigated in TC4 and NAMMA, J. Geophys. Res., 115, D00J08, doi:10.1029/2009JD013017, 2010.

Mason, J. G., Strapp, J. W., and Chow, P.: The ice particle threat to engines in flight. 44th AIAA Aerospace Sciences Meeting, Reno, Nevada, 9-12 January 2006, AIAA-2006-206, 2006.

Matrosov, S. Y.: Retrievals of vertical profiles of ice cloud microphysics from radar and IR measurements using tuned regressions between reflectivity and cloud parameters, J. Geophys. Res., 104, 16741-16753, 1999.

Matrosov, S. Y. and Heymsfield, A. J.: Estimating ice content and extinction in precipitating cloud systems from CloudSat radar measurements, J. Geophys. Res., 113, D00A05, doi:10.1029/2007JD009633, 2008.

Mitchel, D.: Use of mass- and area-dimensional power laws for determining precipitation particle terminal velocity, J. Atmos. Sci., 53, 1710-1723, 1996.

Mitchell, D. L., Zhang, R., and Pitter, R. L.: Mass-dimensional relationships for ice particles and the influence of riming on snowfall rates, J. Appl. Meteor., 29, 153-163, 1990.

Noël, V., Winker, D. M., McGill, M., and Lawson, P.: Classification of particle shapes from lidar depolarization ratio in convective ice clouds compared to in situ observations during CRYSTAL-FACE, J. Geophys. Res., 109, D24213, doi:10.1029/2004JD004883, 2004.

Noël, V., Winker, D. M., Garrett, T. J., and McGill, M.: Extinction coefficients retrieved in deep tropical ice clouds from lidar observations using a CALIPSO-like algorithm compared to in-situ measurements from the cloud integrating nephelometer during CRYSTAL-FACE, Atmos. Chem. Phys., 7, 1415-1422, doi:10.5194/acp-7-1415-2007, 2007.

Platt, C. M. R., Vaughan, M. A., and Austin, R. T.: Characteristics of CALIPSO and CloudSat Backscatter at the Top Center Layers of Mesoscale Convective Systems and Relation to Cloud Microphysics, J. Appl. Meteor. Clim., 50, 368-378, 2011.

Protat, A., Delanoë, J., Bouniol, D., Heymsfield, A. J., Bansemer, A., and Brown, P.: Evaluation of ice water content retrievals from cloud radar reflectivity and temperature using a large airborne in situ microphysical database, J. Appl. Meteor. Clim., 46, 557572, 2007.

Protat, A., Delanoë, J., O’Connor, E., and L'Ecuyer, T.: The evaluation of CloudSat-derived ice microphysical products using ground-based cloud radar and lidar observations, J. Atmos. Oceanic Tech., 27, 793-810, 2010a.

Protat, A., McFarquhar, G., Um, J., and Delanoë, J.: Obtaining best estimates for the micro physical and radiative properties of tropical ice clouds from TWP-ICE in-situ microphysical observations, J. Appl. Meteor. Clim., 50, 895-915, doi:10.1175/2010JAMC2401.1, 2010 b.

Rodgers, C. D.: Inverse Methods for Atmospheric Sounding: Theory and Practice, 238 pp., World Sci., Hackensack, NJ, 2000.

Rosenfeld, D. and Lensky, I. M.: Satellite-based insights into precipitation formation processes in continental and maritime convective clouds, B. Am. Met. Soc., 79, 2457-2476, 1998.

Sayres, D. S., Smith, J. B., Pittman, J. V., Weinstock, E. M., Anderson, J. G., Heymsfield, G., Li, L., Fridlind, M., and Ackerman, A. S.: Validation and determination of ice water contentradar reflectivity relationships during CRYSTAL-FACE: flight requirements for future comparisons, J. Geophys. Res., 113, D05208, doi:10.1029/2007JD008847, 2008.
Stephens, G. L., Tsay, S. C., Stackhouse, P. W., and Flatau, P. J.: The relevance of the microphysical and radiative properties of cirrus clouds to climate and climatic feedback, J. Atmos. Sci., 47, 1742-1753, 1990.

Stephens, G. L., Vane, D. G., Boain, R. J., Mace, G. G., Sassen, K., Wang, Z., Illingworth, A. J., O'Connor, E. J., Rossow, W. B., Durden, S. L., Miller, S. D., Austin, R. T., Benedetti, A., Mitrescu, C., and CloudSat Science Team: The CloudSat mission and the A-TRAIN: A new dimension to space-based observations of clouds and precipitation, B. Am. Meteorol. Soc., 83, 1771-1790, 2002.

Stith, J. L., Dye, J., Bansemer, A., Heymsfield, A. J., Grainger, C. A., Petersen, W. A., and Ciffelli, R.: Microphysical observations of tropical clouds, J. Appl. Meteorol., 41, 97-117, 2002.

Stith, J. L., Avallone, L., Bansemer, A., Basarab, B., Dorsi, S. W., Fuchs, B., Lawson, R. P., Rogers, D. C., Rutledge, S., and Toohey, D. W.: Ice particles in the upper anvil regions of mid-latitude continental thunderstorms: the case for frozen-drop aggregates, Atmos. Chem. Phys. Discuss., 13, 27019-27052, doi:10.5194/acpd-13-27019-2013, 2013.

Strapp, J. W., Chow, P., Maltby, M., Bezer, A. D., Korolev, A., Stromberg, I., and Hallett, J.: Cloud microphysical measurements in thunderstorm outflow regions during Allied/BAe 1997 flight trials, 37th AIAA Aerospace Sciences Meeting and Exhibit, Reno, NV, 11-14 January, 1999, AIAA 99-0498, 1999.

Takano, Y. and Liou, K.-N.: Solar radiative transfer in cirrus clouds. Part I. Single-scattering and optical properties of hexagonal ice crystals, J. Atmos. Sci., 46, 3-19, 1989.

Takano, Y. and Liou, K.-N.: Radiative transfer in cirrus clouds. Part III: Light scattering by irregular ice crystals, J. Atmos. Sci., 52, 818-837, 1995.

Wang, P. K.: Recent evidences of deep convective transport through the tropopause, American Geophysical Union, Fall Meeting 2007, abstract \#A33H-06, 2007.

Winker, D. M., Pelon, J., and McCormick, M. P.: The CALIPSO mission: Spaceborne lidar for observation of aerosols and clouds, Status and Performance, Proceedings of SPIE, 4893, 1-11, 2003.

Winker, D. M., Vaughan, M. A., Omar, A. H., Hu, Y., Powell, K. A., Liu, Z., Hunt, W. H., and Young, S. A.: Overviewof the CALIPSO mission and CALIOP data processing algorithms, J. Atmos. Ocean. Tech., 26, 2310-2323, 2009.

Winker, D. M., Pelon, J., Coakley Jr., J. A., Ackerman, S. A., Charlson, R. J., Colarco, P. R., Flamant, P., Fu, Q., Hoff, R. M., Kittaka, C., Kubar, T. L., Le Treut, H., McCormick, M. P., Mégie, G., Poole, L., Powell, K., Trepte, C., Vaughan, M. A., and Wielicki, B. A.: The CALIPSO mission: a global 3-D view of aerosols and clouds, B. Am. Meteorol. Soc., 91, 1211-1229, doi:10.1175/2010BAMS3009.1, 2010.

Xie, S.-P. and Carton, J. A.: Tropical Atlantic Variability: Patterns, Mechanisms, and Impacts, Geophysical Monograph, in: Earth Climate: The Ocean-Atmosphere Interaction, edited by: Wang, C., Xie, S.-P., and Carton, J. A., AGU, Washington, DC, 2004.

Yang, P., Baum, B. A., Heymsfield, A. J., Hu, Y. X., Huang, H.L., Tsay, S.-C., and Ackerman, S.: Single-scattering properties of droxtals, J. Quant. Spectrosc. Ra., 79, 1159-1169, 2003. 